\title{
TINJAUAN YURIDIS PENYELENGGARAAN PENGADAAN TANAH BAGI PEMBANGUNAN UNTUK KEPENTINGAN UMUM BERDASARKAN PERATURAN PEMERINTAH NOMOR 19 TAHUN 2021
}

\author{
${ }^{1}$ Sirjon Tenong, ${ }^{2}$ Mustating Daeng Maroa, ${ }^{3}$ Rahmat Setiawan \\ 1,2,3 Fakultas Hukum Universitas Muhammadiyah Luwuk \\ ${ }^{1}$ sirjontenong@gmail.com, ${ }^{2}$ Mustating@yahoo.co.id, \\ ${ }^{3}$ rahmatsetiawan5365@gmail.com
}

\begin{abstract}
ABSTRAK
Penelitian ini bertujuan untuk mengetahui kewenangan Pemerintah dan Pemerintah daerah dalam Penyelenggaraan Pengadaan Tanah Bagi Pembangunan Untuk Kepentingan Umum serta tahapan Penyelenggaraannya berdasarkan Peraturan Pemerintah Nomor 19 Tahun 2021. Jenis penelitian yang dipakai adalah penelitian hukum normative. Pemerintah mempunyai kewenangan dalam penyelenggaraan pengadaan tanah bagi pembangunan untuk kepentingan umum melalui pelaksanaan pengadaan tanah oleh Menteri di bidang agrarial/pertanahan dan tata ruang. Selanjutnya Pemerintah daerah dalam hal ini gubernur/bupati/walikota menyelenggarakan pengadaan tanah pada tahapan perencanaan yaitu menerima dokumen perencanaan pengadaan tanah dari instansi yang memerlukan tanah dan tahap persiapan yaitu membentuk tim persiapan pengadaan tanah bagi pembangunan untuk kepentigan umum. Sedangkan tahapan penyelenggaran pengadaan tanah bagi pembangunan untuk kepentingan umum berdasarkan Peraturan Pemerintah Nomor 19 Tahun 2021 dilaksanakan melalui tahapan kegiatan perencanaan, persiapan, pelaksanaan, dan penyerahan hasil pengadaan tanah.
\end{abstract}

Kata kunci: Pengadaan Tanah, Pembangunan, Kepentingan Umum

\section{ABSTRACT}

This study aims to determine the authority of the Government and local governments in the Implementation of Land Procurement for Development in the Public Interest and the stages of its implementation based on Government Regulation Number 19 of 2021. The type of research used is normative legal research. The government has the authority to carry out land acquisition for development in the public interest through the implementation of land acquisition by the Minister in the field of agrarian/land and spatial planning. Furthermore, the regional government, in this case the 
governor/regent/mayor, organizes land acquisition at the planning stage, namely receiving land acquisition planning documents from agencies that require land and the preparation stage, namely forming a land acquisition preparation team for development in the public interest. Meanwhile, the stages of organizing land acquisition for development in the public interest based on Government Regulation Number 19 of 2021 are carried out through the stages of planning, preparing, implementing, and submitting the results of land acquisition.

Keywords: Land Acquisition, Development, Public Interest

\section{Latar Belakang}

Tujuan Negara Republik Indonesia yang termaktub dalam Pembukaan Undang-Undang Dasar Tahun 1945 adalah mewujudkan masyarakat yang adil, makmur, dan sejahtera berdasarkan Pancasila dan Undang-Undang Dasar Negara Republik Indonesia Tahun 1945. Tujuan tersebut dapat diwujudkan oleh pemerintah dengan cara menyelenggarakan pembangunan. Salah satu upaya yang dilakukan dalam rangka mewujudkan pembangunan nasional yaitu dengan melaksanakan pembangunan untuk Kepentingan Umum.

Pembangunan yang dilakukan untuk kepentingan umum tentunya memerlukan tanah yang pengadaannya dilaksanakan dengan mengedepankan prinsip yang terkandung di dalam Undang-Undang Dasar Negara Republik Indonesia Tahun 1945 dan hukum tanah nasional. Adapun beberapa prinsip yang dianut adalah prinsip kemanusiaan, keadilan, kemanfaatan, kepastian, keterbukaan, kesepakatan, keikutsertaan, kesejahteraan, keberlanjutan, dan keselarasan sesuai dengan nilai-nilai berbangsa dan bernegara.

Perencanaan pembangunan yang telah disusun sebelumnya oleh pemerintah atau pemerintah daerah diperlukan sebidang tanah tertentu dalam rangka pembangunan untuk kepentingan umum tersebut, namun dalam kenyataannya tanah yang menjadi lokasi pembangunan telah melekat hak. Meningkatnya penggunaan tanah untuk berbagai kegiatan pembangunan untuk kepentingan, oleh Sudaryo Soimin (2004:79) mengatakan bahwa, "Tanah negara yang tersedia untuk keperluan pembangunan sudah sangat terbatas sekali atau tidak ada lagi”. 
Untuk permasalahan tersebut Pemerintah menerbitkan Undang-undang Nomor 2 Tahun 2012 tentang Pengadaan Tanah Bagi Pembangunan Untuk Kepentingan Umum (UU Nomor 2 Tahun 2012) beserta peraturan pelaksanaan dalam bentuk Peraturan Presiden. Kehadiran Undang-undang tersebut merupakan amanat Pasal 18 Undang-Undang Nomor 5 Tahun 1960 Tentang Peraturan Dasar Pokok-Pokok Agraria (UUPA) yang menjelaskan bahwa "Untuk kepentingan umum, termasuk kepentingan bangsa dan Negara serta kepentingan bersama dari rakyat, hakhak atas tanah dapat dicabut, dengan memberi ganti kerugian yang layak dan menurut cara yang diatur dengan undang-undang".

Pada prinsipnya setiap hak atas tanah harus memiliki "fungsi sosial" dimana pada hak tersebut juga melekat kepentingan sosial yang harus dihargai dan diberikan hak oleh pemilik tanah tersebut (Achmad Rubaie, 2007:16). Pengadaan tanah berdasarkan Konsepsi Hukum Tanah Nasional harus menciptakan keseimbangan antara kepentingan umum dan kepentingan perseorangan. Sehingga prinsip pengadaan tanah ialah mewujudkan pengadaan tanah yang memenuhi rasa keadilan, baik bagi masyarakat yang terkena pengadaan tanah untuk mendapatkan ganti rugi yang layak demi kelangsungan hidup mereka dan pemerintah maupun pemerintah daerah dapat memperoleh tanah untuk pembangunan.

Dewasa ini berbagai kegiatan pembangunan untuk kepentingan umum, telah dilakukan pemerintah, yang salah satunya ialah pembangunan infrastruktur yang tersebar diseluruh wilayah Negara Indonesia. Pembangunan infrastruktur tersebut tentunya juga membutuhkan tanah, sehingga prosedur pengadaan tanah mempunyai peran yang sangat penting untuk mendukung pembangunan infrastruktur nasional tersebut.

Untuk menghadapi permasalahan pembangunan infrastruktur nasional dan peningkatan investasi, maka Pemerintah dan DPR menyepakati Undang-Undang 11 tahun 2020 tentang Cipta Kerja. Undang-undang tersebut dikenal dengan prinsip omnibus law yang mana salah satu materi muatannya ialah mengubah Undang-Undang 2 tahun 2012 tentang Pengadaan Tanah bagi Pembangunan untuk Kepentingan Umum. Hal ini 
bertujuan untuk melakukan 2012 tentang Penyelenggaraan penyederhanaan aturan, penciptaan Pengadaan Tanah bagi Pembangunan lapangan kerja, pemberdayaan untuk Kepentingan Umum.

masyarakat, peningkatan ekosistem Beberapa perubahan yang investasi, dan percepatan Proyek menjadi dasar lahirnya PP 19 tahun Strategis Nasional, termasuk 2021 tentang Penyelenggaraan peningkatan perlindungan dan Pengadaan Tanah bagi Pembangunan kesejahteraan pekerja. untuk Kepentingan Umum

Untuk melaksanakan Undang- (https://www.jogloabang.com/sosial/ppUndang Nomor 11 Tahun 2020 tersebut 19-2021-penyelenggaraan-pengadaanmembutuhkan berbagai Peraturan tanah-pembangunan-kepentinganPemerintah sebagai aturan pelaksanaannya. Untuk penyelenggaraan pengadaan tanah bagi pembangunan untuk kepentingan umum, diterbitkanlah Peraturan Pemerintah Nomor 19 Tahun 2021 tentang Penyelenggaraan Pengadaan Tanah bagi Pembangunan untuk Kepentingan Umum, yang mencabut aturan pelaksana dari undangUndang Nomor 2 Tahun 2002 yaitu mencabut Peraturan Presiden Nomor 71 Tahun 2012 tentang Penyelenggaraan Pengadaan Tanah bagi Pembangunan untuk Kepentingan Umum (Lembaran Negara Republik Indonesia Tahun 2012 Nomor 156) sebagaimana telah beberapa kali diubah terakhir dengan Peraturan Presiden Nomor 148 Tahun 2015 tentang Perubahan Keempat atas Peraturan Presiden Nomor 71 Tahun umum, diakses 10 April 2021) adalah karena dibutuhkannya pengaturan dalam bentuk peraturan pemerintah yang lebih sederhana dan efektif dalam hal:

1. Penambahan kriteria pembangunan untuk Kepentingan Umum;

2. Upaya percepatan Pengadaan Tanah termasuk penyelesaian status kawasan hutan;

3. Percepatan Pengadaan Tanah terkait dengan tanah kas desa, tanah wakaf, tanah aset;

4. Pelibatan lembaga pertanahan untuk membantu dalam penyusunan dokumen perencanaan pengadaan Tanah;

5. Penambahan jangka waktu Penetapan Lokasi; dan 6. Penitipan Ganti Kerugian. 
Berdasarkan uraian tersebut, penulis akan melakukan analisis terhadap Peraturan Pemerintah No 19 Tahun 2021 mengenai kewenangan Pemerintah dan Pemerintah daerah dalam Penyelenggaraan Pengadaan Tanah Bagi Pembangunan Untuk Kepentingan Umum Berdasarkan Peraturan Pemerintah Nomor 19 Tahun 2021 serta tahapan Penyelenggaraan Pengadaan Tanah Bagi Pembangunan Untuk Kepentingan Umum.

\section{Metode Penelitian}

Metode penelitian merupakan arah atau petunjuk dalam melaksanakan penelitian. Adapun metode penelitian yang digunakan adalah penelitian hukum normatif. Menurut Mukti Fajar dan Yulianto Ahmad (2013) penelitian hukum normative merupakan penelitian yang meletakkan hukum sebagai bangunan sistem norma. Artinya bahwa penelitian dilakukan dengan meneliti bahan kepustakaan. Sumber data dalam penelitian ini adalah melalui penelitian pustaka (library research), yaitu menelah berbagai buku kepustakaan, dan karya ilmiah yang ada hubungannya dengan permasalahan penelitian.

\section{Hasil dan Pembahasan}

A. Kewenangan Pemerintah dan Pemerintah daerah dalam

Penyelenggaraan Pengadaan

Tanah Bagi Pembangunan Untuk

Kepentingan Umum Berdasarkan

Peraturan Pemerintah Nomor 19

Tahun 2021

Pengadaan tanah untuk kepentinggan umum adalah upaya untuk menuju masyarakat Indonesia yang sejahtera, adil, dan makmur melalui penyelenggaraan pembangunan nasional. Pembangunan nasional tersebut dilaksanakan oleh pemerintah dan pemerintah daerah. Namun pada prinsipnya pembangunan fisik selalu memerlukan tanah.

Konsep tanah di Indonesia mengacu pada Pasal 33 ayat 3 UndangUndang Dasar Negara Republik Indonesia tahun 1945 (UUD NRI 1945). Selanjutnya Pasal 33 ayat (3) UUD NRI 1945 dijabarkan dalam Pasal 2 ayat (2) Undang Undang No 5 Tahun 1960 tentang Peraturan Dasar Pokok Pokok Agraria atau yang lebih dikenal dengan Undang-Undang pkok Agraria (UUPA). Dari kedua Pasal tersebut memberikan makna penguasaan Negara atas tanah. Menurut Aminuddin Salle, dkk 
(2010:73) bahwa hak menguasai dari Negara mengandung maksud:

a. Mengatur dan menyelenggarakan peruntukan, penggunaan, persedian, dan pemeliharaan bumi, air dan ruang angkasa;

b. Menentukan dan mengatur berbagai hubungan hukum antara subjek hukum dengan bumi, air, dan ruang angkasa;

c. Menentukan dan mengatur hubungan hukum antar subjek hukum dan perbuatan-perbuatan hukum yang berkaitan dengan bumi, air, dan ruang angkasa.

Menurut Muhamad Bakri (Hardianto Djanggih dan Salle, 2017:168) menyebutkan bahwa berdasarkan sifat dan dasarnya, hak menguasai dari Negara melahirkan kewenangan Negara yang laksanakan oleh pemerintah pusat. Adapun pemerintah daerah memperoleh kewenangan jika terjadi pelimpahan kewenangan dari pemerintah pusat kepada pemerintah daerah.

Hal tersebut berkaitan dengan penyelenggaraan pemerintahan di Negara Kesatuan Republik Indonesia yang menganut asas desentralisasi. Menurut Sirojul Munir (2014:114) bahwa "desentralisasi bukan berarti akan meninggalkan asas sentralisasi. Sehingga menurutnya bahwa desentralisasi tanpa adanya sentralisasi maka akan melahirkan disintegrasi." Oleh karena itu penyelenggaraan pemerintahan otonomi daerah mengandung maksud bahwa kebebasan pemerintah daerah dalam mengelola sistem pemerintahannya membutuhkan pembinaan dan pengawasan dari pemerintah pusat dalam bingkai Negara kesatuan Republik Indonesia.

Dalam penyelenggaraan pemerintahan dibagi menjadi urusan pemerintahan absolut, konkuren dan umum. Urusan pemerintahan absolut merupakan kewenangan mutlak pemerintah pusat, sedangkan urusan pemerintahan konkuren merupakan urusan pemerintahan yang dibagi anatara pemerintah pusat dan daerah. Adapun urusan pemerintahan umum adalah urusan pemerintahan yang menjadi kewenangan presiden sebagai kepala pemerintahan.

Berdasarkan ketentuan Pasal 11 Undang-Undang Nomor 23 tahun 2014 tentang Pemerintahan Daerah (UU No. 23 Tahun 2014) bahwa urusan konkuren menjadi kewenangan daerah terdiri atas 
urusan pemerintahan wajib dan pilihan. Sedangkan urusan pemerintahan wajib terdiri atas urusan yang berkaitan dengan pelayanan dasar dan tidak berkaitan dengan pelayanan dasar.

Adapun bidang pertanahan berdasarkan ketentuan Pasal 12 ayat (2) UU No. 23 tahun 2014 merupakan urusan pemerintahan wajib yang tidak berkaitan dengan pelayanan dasar. Dari berbagai ketentuan tersebut menjelaskan bahwa bidang pertanahan merupakan urusan pemerintahan yang dibagi antara pemerintah pusat dan pemerintah daerah.

Selanjutnya dalam hal pengadaan tanah untuk kepentingan umum pada Pasal 4 Undang-Undang Nomor 2 Tahun 2012 Tentang Pengadaan Tanah Bagi Pembangunan Untuk Kepentingan Umum (UU No. 2 Tahun 2012) menyebutkan bahwa Pemerintah dan/atau Pemerintah Daerah memberikan jaminan ketersedian tanah dan pendanaan untuk kepentingan umum. Sedangkan pada Pasal 6 UU No. 2 Tahun 2012 disebutkan bahwa Pengadaan tanah untuk kepentingan umum diselenggarakan oleh pemerintah.

Dalam rangka penyelenggaraan pengadaan tanah bagi pembangunan untuk Kepentingan umum dilakukan oleh instansi yang memerlukan tanah. Berdasarkan Pasal 8 Ayat (2) Peraturan Pemerintah Nomor 19 tahun 2021 tentang Penyelenggaraan Pengadaan Tanah Bagi Pembangunan Untuk Kepentingan Umum (PP No.1 Tahun 2021) bahwa "Dokumen perencanaan Pengadaan Tanah oleh Instansi yang Memerlukan Tanah diajukan kepada gubernur/ bupati/wali kota." Hal ini menunjukkan bahwa pemerintah daerah dalam hal ini gubernur/bupati atau walikota menerima dokumen perencanaan pengadaan tanah yang dibuat oleh instansi yang memerlukan tanah.

Sedangkan pada saat persiapan pengadaan tanah gubernur membentuk tim persiapan setelah menerima dokumen penecanaan pengadaan tanah (Pasal 9 PP No.1 Tahun 2021). Selanjutnya dalam hal pengadaan tanah dengan skala kecil yaitu tidak lebih dari dari 5 (lima) hektar, berdasarkan Pasal 500 ayat (1) PP No.1 Tahun 2021 "Gubernur dapat mendelegasikan kewenangan pelaksanaan persiapan pembangunan pengadaan Tanah bagi untuk Kepentingan Umum kepada bupati/wali kota berdasarkan 
pertimbangan efisiensi, efektivitas, kondisi geografis, sumber daya manusia, dan pertimbangan lainnya, dalam waktu paling lama 3 (tiga) Hari sejak diterimanya dokumen perencanaan Pengadaan Tanah."

Adapun pelaksanaan pengadaan tanah berdasarkan ketentuan Pasal 51 ayat (1) dan (2) PP No.1 Tahun 2021bahwa Pelaksanaan Pengadaan Tanah diselenggarakan oleh Menteri, melalui kepala Kantor Wilayah selaku ketua pelaksana Pengadaan Tanah. Sedangkan Menteri yang dimaksud adalah menteri yang menyelenggarakan urusan pemerintahan di bidang agrarial/pertanahan dan tata ruang. Hal ini sebagaimana yang dikemukakan oleh Muwahid, (2018:326) bahwa "kewenangan Pemerintah untuk melaksanakan pengadaan tanah untuk kepentingan umum mendasari asas yang diatur pada Pasal 6 UUPA bahwa semua hak atas tanah berfungsi sosial."

Berdasarkan ketentuan dalam Peraturan Pemerintah Nomor 19 Tahun 2021 bahwa pemerintah mempunyai kewenangan dalam penyelenggaraan pengadaan tanah bagi pembangunan untuk kepentingan umum melalui pelaksanaan pengadaan tanah oleh
Menteri di bidang agrarial/pertanahan dan tata ruang. Selanjutnya Pemerintah daerah dalam hal ini gubernur/bupati/walikota menyelenggarakan pengadaan tanah pada tahapan perencanaan yaitu menerima dokumen perencanaan pengadaan tanah dari instansi yang memerlukan tanah dan tahap persiapan yaitu membentuk tim persiapan pengadaan tanah bagi pembangunan untuk kepentigan umum.

\section{B. Tahapan Penyelenggaraan Pengadaan Tanah Bagi Pembangunan Untuk Kepentingan Umum Berdasarkan Peraturan Pemerintah Nomor 19 Tahun 2021 Penyelenggaraan pengadaan} tanah bagi pembangunan untuk kepentingan umum adalah upaya dalam rangka melaksanakan pembangunan nasional. Tentunya pembangunan nasional bertujuan untuk kesejahteraan masyarakat. Dalam pelaksanaan pembangunan fisik membutuhkan tanah. Sebagaimana kita ketahui bahwa kebutuhan akan tanah dimasyarakat sangatlah tinggi, namun ketersedian tanah tidaklah bertambah.

Hal ini sebagaimana yang dikemukakan oleh Hardianto Djanggih 
dan Salle (2017:170) bahwa "dalam melaksanakan program pembangunan yang yang menjadi instansi pemerintah, secara ex officio membutuhkan ketersedian lahan atau tanah untuk merealisasikan pembangunan sarana dan prasarana dalam menunjang kepentingan umum. Adapun yang maksud kepentingan umum tidak kemudian berpotensi menjadikan masyarakat sengsara, namun akan memberi peningkatan kemakmuran dan kesejahteraan rakyat."

Sehingga untuk memenuhi kebutuhan tanah dalam rangka pembangunan untuk kepentingan umum, namun tetap menghormati hak-hak yang melekat pada tanah maka perlu dilakukan penyelenggaraan pengadaan tanah. Ketentuan tentang pengadaan tanah untuk kepentingan umum telah terjadi beberapa kali perubahan. Namun terakhir dengan Undang-undang Nomor 2 tahun 2012 tentang Pengadaan Tanah Bagi Pembangunan Untuk Kepentingan Umum, namun kemudian diperbaharui dengan Undang-undang Nomor 11 tahun 2020 tentang Cipta Kerja (UU No. 11 tahun 2020). Untuk melaksanakan ketentuan UU No. 11 tahun 2020, terbitlah Peraturan pemerintah Nomor
19 tahun 2021 tentang Penyelenggaraan Pengadaaan Tanah Bagi Pembangunan Untuk Kepentingan Umum (PP No. 19 tahun 2021).

Tahapan Pengadaan Tanah Bagi Pembangunan Untuk Kepentingan Umum berdasarkan Peraturan Pemerintah Nomor 19 Tahun 2021 pada Pasal 3, dilaksanakan melalui tahapan perencanaan, persiapan, pelaksanaan, dan penyerahan hasil, yang akan diuraikan berikut ini:

\section{Perencanaan}

Untuk menjadi dasar perencanaan pengadaan tanah bagi pembangunan kepentingan umum, instansi yang memerlukan tanah tersebut membuat rencana pengadaan tanah, sesuai Pasal 4 ayat 1 PP No. 19 tahun 2021 harus berdasarkan pada:

a. rencana tata ruang; dan

b. prioritas pembangunan yang tercantum dalam:

1. rencana pembangunan jangka menengah;

2. rencana strategis; dan/atau

3. rencana kerja pemerintah/Instansi yang Memerlukan Tanah."

Instansi yang memerlukan tanah tersebut terdiri atas "lembaga 
negara, kementerian, lembaga pemerintah nonkementerian, pemerintah provinsi, pemerintah kabupaten/kota, Badan Bank Tanah dan badan hukum milik negara/badan usaha milik Negara/badan usaha milik daerah yang mendapat penugasan khusus Pemerintah Pusat/Pemerintah Daerah atau Badan Usaha yang diberikan kuasa sesuai dengan perjanjian dari lembaga negara, kementerian, lembaga pemerintah nonkementerian, pemerintah provinsi, pemerintah kabupaten/kota, badan hukum milik Negara/badan usaha milik negara yang mendapat penugasan khusus Pemerintah Pusat/Pemerintah Daerah dalam rangka penyediaan infrastruktur untuk Kepentingan Umum.” (Pasal 1 angka 1 PP No. 19 tahun 2021).

Rencana pengadaan tanah tersebut dibuat dalam bentuk dokumen. Sesuai Pasal 6 ayat (1) PP No. 19 tahun 2021, dokumen tersebut paling sedikit memuat:

a. maksud dan tujuan rencana pembangunan;

b. Kesesuaian Kegiatan Pemanfaatan Ruang; c. prioritas pembangunan nasional/daerah;

d. letak tanah;

e. luas tanah yang dibutuhkan;

f. gambaran umum status tanah;

g. perkiraan jangka waktu pelaksanaan Pengadaan Tanah;

h. perkiraan jangka waktu pelaksanaan pembangunan;

i. perkiraan nilai tanah;

j. rencana penganggaran; dan

k. preferensi bentuk Ganti Kerugian."

Selain itu dokumen perencanaan pengadaan tanah, berdasarkan Pasal 7 ayat (1) PP No. 19 tahun 2021disusun sesuai studi kelayakan yang meliputi:

a. survei sosial ekonomi;

b. kelayakan lokasi;

c. analisis biaya dan manfaat pembangunan bagi wilayah dan masy arakat;

d. perkiraan nilai tanah;

e. dampak lingkungan dan dampak sosial yang mungkin timbul akibat dari Pengadaan Tanah dan pembangunan; dan

f. studi lain yang diperlukan.

Selanjutnya dokumen perencanaan pengadaan tanah tersebut ditetapkan oleh pimpnan atau pejabat yang ditunjuk mewakili instansi yang memerlukan tanah. 
Setelah itu dokumen tersebut diajukan

kepada

Gubernur/Bupati/Walikota.

\section{Persiapan}

Setelah
perencanaan pengadaan tokumen
diterima, maka gubernur
melaksanakan tahapan kegiatan
persiapan. Sesuai dengan Pasal 9 PP
No. 19 tahun 2021, bahwa pada
tahapan persiapan tersebut, gubernur
membentuk Tim Persiapan yang
beranggotakan:

a. Bupati/Wali kota,

b. Perangkat daerah provinsi terkait,

c. Instansi yang Memerlukan Tanah,

d. Instansi pemerintah yang menyelenggarakan urusan di bidang pertanahan, dan

e. Instansi terkait lainnya yang dianggap perlu.

Dalam rangka kelancaran pelaksanaan tugas tim persiapan, maka gubernur membentuk sekretariat persiapan pengadaan tanah yang bertempat di Sekretariat Daerah Provinsi. Tugas tim persiapan sesuai dengan Pasal 11 PP No. 19 tahun 2021 adalah sebagai berikut: a. Melaksanakan pemberitahuan rencana pembangunan Tim persiapan melakukan pemberitahuan kepada masyarakat yang berada dilokasi rencana pembangunan. Pemberitahuan tersebut paling lama 3 (tiga) hari setelah tim terbentuk. Sesuai dengan Pasal 12 ayat (3) PP No. 19 tahun 2021, bahwa pemberitahuan tersebut memuat informasi tentang:

1) maksud dan tujuan rencana pembangunan;

2) letak tanah dan luas tanah yang dibutuhkan;

3) tahapan rencana Pengadaan Tanah;

4) perkiraan jangka waktu pelaksanaan Pengadaan Tanah;

5) perkiraan jangka waktu pelaksanaan pembangunan; dan

6) informasi lainnya yang dianggap perlu."

Adapun bentuk pemberitahuan tersebut dapat dilakukan secara langsung atau tidak langsung. Pemberitahuan secara langsung dapat berupa sosialisasi, tatap muka, dan/atau surat pemberitahuan. Sedangkan secara tidak langsung dilakukan 
melalui media cetak atau media elektronik.

b. Melaksanakan pendataan awal lokasi rencana pembangunan

Pendataan awal yang dilakukan tim persiapan pada lokasi rencana pembangunan untuk mengetahui pihak-pihak yang berhak dan objek pengadaan tanah. Adapun pihak yang berhak berdasarkan ketentuan Pasal 18 ayat (2) PP No. 19 tahun 2021adalah sebagai berikut:

1) pemegang Hak Atas Tanah;

2) pemegang Hak Pengelolaan;

3) nazhtr untuk tanah wakaf;

4) pemegang alat bukti tertulis hak lama;

5) masyarakat hukum adat;

6) pihak yang menguasai Tanah Negara dengan iktikad baik;

7) pemegang dasar penguasaan atas tanah; dan/atau

8) pemilik bangunan, tanaman, atau benda lain yang berkaitan dengan tanah.

Pendataan awal

dilakukan oleh tim persiapan sejak tanggal dilakukan sosialisasi hingga paling lama 30 (tiga puluh) hari, bersama dengan pejabat pemerintah kelurahan atau desa. Hasil pendataan dibuat dalam bentuk daftar sementara pihak yang berhak dan objek pengadaan tanah pada lokasi pengadaan sebagai bahan dalam melaksanakan konsultasi pubik.

c. Melaksanakan Konsultasi Publik rencana pembangunan

Tim persiapan melaksanakan konsultasi publik untuk rencana pembangunan dalam rangka untuk mendapatkan kesepakatan dari pihak yang berhak, pengelola barang, pengguna barang, dan masyarakat yang terkena dampak, hal ini sesuai dengan Pasal 29 PP No. 19 tahun 2021. Hasil kesepakatan perihal rencana pembangunan dibuatkan dalam berita acara kesepakatan.

Apabila dalam hasil konsultasi publik tidak tercapai kesepakatan dimana terdapat pihak yang keberatan, maka berdasarkan ketentuan Pasal 34 PP No. 19 tahun 2021, gubernur 
membentuk Tim Kajian atas keberatan tersebut yang beranggotakan:

1) Sekretaris Daerah Provinsi atau pejabat yang ditunjuk sebagai ketua merangkap anggota;

2) Kepala Kantor Wilayah sebagai sekretaris merangkap anggota;

3) instansi yang menangani urusan pemerintahan di bidang perencanaan

pembangunan daerah sebagai anggota;

4) Kepala Kantor Wilayah Kementerian Hukum dan Hak Asasi Manusia sebagai anggota;

5) Bupati/walikota atau pejabat yang ditunjuk sebagai anggota; dan

6) akademisi sebagai anggota."

Penanganan terhadap keberatan yang diajukan dilakukan paling lama 14 (empat belas) hari. Sesuai dengan Pasal 37 PP No. 19 tahun 2021, bahwa

Gubernur berdasarkan rekomendasi Tim Kajian dapat menolak atau menerima keberatan terhadap lokasi rencana pembangunan. Apabila dalam keputusannya gubernur menerima keberatan, maka instansi yang memerlukan tanah membatalkan rencana pengadaan tanah atau memindahkan lokasi pembangunan ke bidang tanah yang lain.

d. Menyiapkan Penetapan Lokasi pembangunan

Instansi yang memerlukan tanah mengajukan permohonan penetapan lokasi pembangunan dengan melampirkan peta lokasi kepada gubernur (Pasal 44 PP No. 19 tahun 202) berdasarkan hasil kesepakatan Tim Persiapan dengan pihak yang berhak, atau berdasarkan keputusan penolakan keberatan. Yang selanjutnya gubernur menerbitkan penetapan lokasi pembangunan.

Apabila gubernur tidak menerbitkan penetapaan lokasi pembangunan dalam jangka waktu 14 (empat belas) hari bagi Pengadaan Tanah untuk tujuan pembangunan Proyek Strategis Nasional, atau mendesak dan/atau pembangunan yang tidak dapat dipindahkan lokasinya, maka Menteri dapat 
melakukan penetapan lokasi dengan cara Instansi yang Memerlukan Tanah dapat mengajukan permohonan

Penetapan lokasi kembali kepada menteri.

e. Mengumumkan Penetapan

Lokasi pembangunan untuk Kepentingan Umum

Gubernur dan instansi yang memerlukan tanah mengumumkan Penetapan Lokasi pembangunan untuk Kepentingan Umum. Pengumuman dapat dilakukan dengan menempatkan di kantor desa/kelurahan, kantor camat atau melalui media. Hal ini berdasarkan Pasal 49 ayat (1) PP No. 19 Tahun 2021, bahwa pengumuman tersebut dilakukan dengan cara:

1. ditempatkan di kantor kelurahan/desa atau nama lain, kantor kecamatan, dan/atau kantor bupati/wali kota dan di lokasi pembangunan; dan

2. diumumkan melalui media media elektronik.
Berdasarkan tugas dari Tim Persiapan yang dibentuk oleh gubernur bahwa kegiatannya dimulai dari pemberitahuan, pendataan awal, konsultasi publik, penetapan lokasi dan pengumuman lokasi rencana pembangunan. Dalam keadaan tertentu tahapan persiapan tersebut dapat didelegasikan pelaksanaannya kepada Bupati/Walikota.

Hal ini sebagaimana yang diatur dalam ketentuan Pasal 50 ayat (1) bahwa "Gubernur dapat mendelegasikan kewenangan pelaksanaan persiapan pembangunan pengadaan Tanah bagi untuk Kepentingan Umum kepada bupati/wali kota berdasarkan pertimbangan efisiensi, efektivitas, kondisi geografis, sumber daya manusia, dan pertimbangan lainnya, dalam waktu paling lama 3 (tiga) Hari sejak diterimanya dokumen perencanaan Pengadaan Tanah.”

Paling lama 5 (lima) hari setelah pendelagasian oleh gubernur maka bupati/walikota membentuk Tim Persiapan, 
dimana prosedur pelaksanaan tahapan persiapan berlaku secara mutatis mutandis sebagaimana Tim Persiapan yang dibentuk oleh gubernur.

\section{Pelaksanaan}

Sebagaimana yang diatur pada ketentuan Pasal 53 ayat (1) PP No. 19 Tahun 2021, bahwa "pelaksanaan pengadaan tanah diselenggarakan oleh menteri". Hal ini menunjukkan bahwa pada tahapan pelaksanaan pengadaan tanah bagi pembangunan untuk kepentingan umum merupakan kewenangan pemerintah pusat melalui menteri yang melaksanakan urusan pemerintahan dibidang agrarian/pertanahan dan tata ruang.

Dalam pelaksanaannya, pengadaan tanah dilakukan oleh Kepala Kantor wilayah Badan Pertanahan Nasional dengan membentuk Pelaksana Pengadaan Tanah. Sesuai dengan Pasal 55 ayat (2) PP No. 19 Tahun 2021, susunan keanggotaan Pelaksana pengadaan Tanah paling kurang terdiri dari:

a. Pejabat yang membidangi urusan Pengadaan Tanah di lingkungan Kantor Pertanahan; b. Pejabat pada Kantor Pertanahan setempat pada lokasi Pengadaan Tanah;

c. Pejabat perangkat daerah kabupaten/kota yang membidangi urusan pertanahan;

d. Camat setempat pada lokasi Pengadaan Tanah; dan

e. Lurah/kepala desa atau nama lain pada lokasi Pengadaan Tanah."

Adapun tim pelaksana pengadaan tanah yang dibentuk melakukan kegiatan-kegiatan sebagai berikut:

a. Penyiapan pelaksanaan

b. Inventarisasi dan identifikasi

c. Penetapan Penilai

d. Musyawarah Penetapan bentuk ganti kerugian

e. Pemberian ganti kerugian

f. Penitipan ganti kerugian

g. Pelepasan objek pengadaan tanah

h. Pemutusan hubungan hukum antara pihak yang berhak dengan objek pengadaan tanah

1. Pendokumentasian data administrasi pengadaan tanah

Seluruh kegiatan tersebut merupakan tahapan kegiatan pelaksanaan pengadaan tanah bagi pembangunan untuk kepentingan umum yang 
dilakukan oleh pelaksana tanah bagi pembangunan untuk pengadaan tanah yang dibentuk kepentingan umum melalui pelaksanaan oleh Kepala Kantor Wilayah Badan Pertanahan.

\section{Penyerahan hasil}

Setelah tahapan kegiatan

pelaksanaan dilaksanakan selanjutnya Ketua Pelaksana pengadaan tanah menyerahkan hasil pengadaan tanah kepada Instansi yang memerlukan tanah dilampiri dengan data pengadaan tanah (Pasal 115 PP No. 19 Tahun 2021). Penyerahan tersebut dilakukan dengan penandatanganan berita acara penyerahan hasil pengadaan tanah.

Pensertipikatan terhadap

tanah hasil pengadaan dilakukan oleh instansi yang memerlukan tanah. Karena sejak penandatanganan berita acara, maka tugas pelaksana pengadaan tanah yang dibentuk Kepala Kantor Wilayah Badan Pertanahan Nasional atas nama menteri telah berakhir.

\section{Kesimpulan}

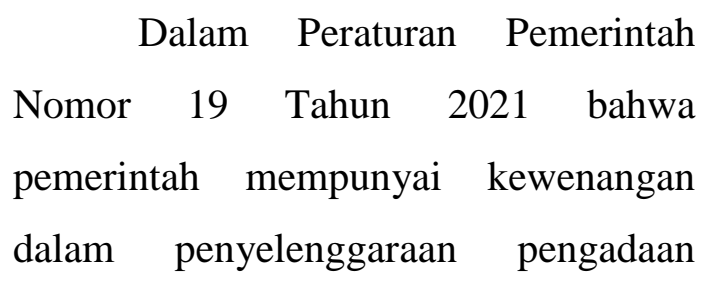

Dalam Peraturan Pemerintah

Nomor 19 Tahun 2021 bahwa dalam penyelenggaraan pengadaan pengadaan tanah oleh Menteri di bidang agrarial/pertanahan dan tata ruang. Selanjutnya Pemerintah daerah dalam hal ini gubernur/bupati/walikota menyelenggarakan pengadaan tanah pada tahapan perencanaan yaitu menerima dokumen perencanaan pengadaan tanah dari instansi yang memerlukan tanah dan tahap persiapan yaitu membentuk tim persiapan pengadaan tanah bagi pembangunan untuk kepentigan umum. Tahapan penyelenggaran pengadaan tanah bagi pembangunan untuk kepentingan umum berdasarkan Peraturan Pemerintah Nomor 19 Tahun 2021 dilaksanakan melalui tahapan kegiatan perencanaan, persiapan, pelaksanaan, dan penyerahan hasil pengadaan tanah.

\section{Daftar Pustaka}

Achmad Rubaie, 2007, Hukum Pengadaan Tanah Untuk Kepentingan Umum, Bayumedia, Surabaya

Aminuddin Salle, dkk, 2010, Bahan Ajar Hukum Agraria, As. Publishing, Makassar

Edi Rohaedi, Isep H. Insan dan Nadia Zumaro, 2019, Mekanisme 
Pengadaan tanah untuk Sumber Perundang-Undangan:

Kepentingan Umum, Pakuan Undang-Undang Dasar Negara Republik

Law Review Volume 5, Nomor

1, Januari-Juni 2019

Hardianto Djanggih, Salle, 2017, Aspek

Hukum Pengadaan Tanah bagi

Pelaksanaan Pembangunan untuk Kepentingan Umum,

Pandecta Volume 12, Nomor 2,

December 2017

Indonesia Tahun 1945

Undang-Undang Nomor 5 Tahun 1960

Tentang Peraturan Dasar PokokPokok Agraria

Undang-Undang Nomor 2 Tahun 2012 tentang Pengadaan Tanah Bagi Pembangunan Untuk Kepentingan Umum

Mukti Fajar, Yulianto Ahmad, 2013, Dualisme Penelitian Hukum Normatif \& Empiris, Pustaka Pelajar, Yogyakarta

Muwahid, 2018, Kewenangan

Pemerintah dalam Pengadaan

Tanah untuk Kepentingan

Umum, AL-DAULAH: Jurnal

Hukum Dan Perundangan Islam

Volume 8, Nomor 2, Oktober

2018

Sirojul Munir, 2013, Hukum

Pemerintahan Daerah Di

Indonesia, Konsep, Azas dan

Aktualisasinya, Genta

Publishing, Yogyakarta.

Sudaryo Soimin, 2004, Status Hak dan

Pembebasan Tanah Edisi Kedua,

Sinar Grafika, Jakarta 